\title{
Toward a New Venture: Building Partnerships with Faculty
}

\section{Ada M. Ducas and Nicole Michaud-Oystryk}

In spring 2000, the authors undertook a study to examine the extent of collaboration between librarians and faculty at the University of Manitoba and to identify the current and future roles of librarians. Two surveys were designed-one directed at faculty, the other at librarians. The current article reports the results of the librarian survey and presents some comparative data between the two surveys. This study demonstrates the extent to which their opinions intersect and examines the quality of the partnership. It measures the impact of the collaboration and describes areas where it could be enhanced and expanded. In addition, the study identifies new roles for librarians that would further enhance the partnership between faculty and librarians.

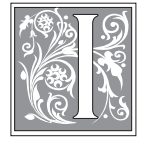

n spring 2000, the authors undertook a study to examine the extent of collaboration between librarians and faculty at the University of Manitoba and to identify the current and future roles of librarians that would enhance the librarian-faculty partnership. Two surveys were designed, one of which was directed at faculty and the other at librarians. In both surveys, five areas were investigated: teaching/instruction, information services, information technology, research, and collections.

The results of the faculty survey were published in College $\&$ Research Libraries in January $2003 .{ }^{1}$ In that article, the au- thors found that established relationships provide a good foundation for ongoing collaboration. The study results showed that faculty highly rate the librarians' role in the university and endorse a greater level of interaction. These ratings reflect the high expectations that faculty have of librarians and the integral role they see librarians playing in the educational process.

The current article reports the results of the librarian survey and presents some comparative data between the two surveys. It examines the level of collaboration between the librarians and the faculty, reports the librarians' assessment of their role at the university, and identifies new

Ada M. Ducas is head of the Neil John Maclean Health Sciences Library in Winnipeg, Manitoba; e-mail: Ada_ducas@umanitoba.ca. Nicole Michaud-Oystryk is head of the Elizabeth Dafoe Library in Winnipeg, Manitoba; e-mail:nicole_michaud-oystryk@umanitoba.ca. The authors would like to acknowledge the Social Sciences and Humanities Research Council of Canada and the University of Manitoba for the SSHRCI UM Research Grant, the University of Manitoba Libraries for financial and research support, and Dr. D. Murphy, Statistical Advisory Service, University of Manitoba, for statistical support. 
roles and attitudes that librarians must adopt in order to become a more integral part of the academic community.

Librarians have long recognized that information technology is changing their roles and responsibilities. As a result of the acquisition of new skills, librarians can play an increasingly critical role in the evaluation, analysis, and filtering of information, and become active partners with faculty in the educational process and in scholarly communication.

\section{Literature}

Recent library literature has challenged librarians to rethink their role and to build partnerships with faculty. In a key article, Sheila D. Creth stressed the need for librarians to redefine and expand their role in the areas of instruction, information and the scholarly process, knowledge management, and organization of networked information resources. She also discussed the importance of librarians as an integral part of the institution and the user community they serve. ${ }^{2}$ In their article, Carla Stoffle, Barbara Allen, and Janet Fore set strategies for meeting the challenges: "To successfully compete, we must leverage our resources, redirect our priorities, collaborate, take risks, and reinvent our organizations. Within our institutions we must move to the beginning of the learning and knowledge creation processes becoming partners with the faculty." ${ }^{3}$ Recognizing progress on that front, Doug Cook stated that the paradigm shifts have "forced librarians to rethink their role in academia" and that, as a result, "connections have been created between the library and the rest of the campus." ${ }^{4}$ Although numerous publications have discussed the collaboration between librarians and faculty in specific areas of responsibility, the authors identified only a small number of studies published in the past decade that report survey data and, in that sense, relate to their study. Mary Lynn Rice-Lively and J. Drew Racine conducted a case study at a large research library to gather perceptions and observations about the changing role of librarians from the perspective of students, library and information sciences faculty, and academic librarians. ${ }^{5}$ A noteworthy article by Evan St. Lifer reported on a survey that aimed to determine to what degree librarians' jobs are changing and why. ${ }^{6}$ Bee Gallegos and Thomas Wright reported the results of a survey posted on electronic discussion lists dealing with the types of projects librarians and faculty pursued in collaboration. ${ }^{7}$

In recent years, a number of articles have been published on librarians' roles. Mick O'Leary contended that librarians have defined new technical, service, and administrative competencies as a result of the changes brought about by information technology but stressed that "new roles must be understood as attitudes, aptitudes, and approaches, as a set of capabilities that can be quickly and effectively applied to whatever new need or opportunity arises." ${ }^{8}$ Patrick J. Hunt has viewed librarians as having "a role to play in the crucial activity of shaping context." 9 This view also is held by Paul Saffo, who has stated that "the future belongs to neither the conduit or content players but those who control the filtering, searching, and sense-making tools we will rely on to navigate through the expanses of cyberspace." 10

\section{Methodology}

A survey developed by the authors was sent to forty-seven full-time academic librarians at the University of Manitoba in March 2000. The survey was an attempt at a census, and therefore the results are representative only of those who responded and are to be viewed as descriptive in nature. The questionnaires were coded to facilitate 
two follow-up mailings to nonrespondents. Librarians were assured that their replies would be confidential and that the study had been reviewed and approved by the university's Faculty of Arts Ethics Review Committee. The R statistical software was used to compute the results. ${ }^{11}$

Each of the five sections of the questionnaire has a preliminary question yielding a yes or no response. Within each section, the remaining follow-up questions, except for the impact question, allow multiple responses to the various options. Where possible, the results of this survey are compared to those of the faculty survey conducted at the same time. The faculty survey was sent to all 1,400 full-time faculty members at the University of Manitoba.

\section{Survey Instrument}

The survey, a seven-page questionnaire, asked respondents to indicate the following:

- whether they had or had not interacted with faculty in the five areas of investigation; if they had not interacted, what their reasons were; if they had, what the type of interaction was;

- other ways librarians could contribute;

- what responsibilities librarians could/should relinquish in order to perform new functions;

- the importance of the librarians' role in the university.

For the most part, the questions were close ended; the researchers provided what they considered to be the most probable choices and invited respondents to check as many as applied. Respondents were given the opportunity to provide additional possibilities in an "other" category and to provide general comments at the end.

\section{Respondents}

The final number of usable responses was forty-one, or 87 percent of the population surveyed. Because librarians at the University of Manitoba enjoy academic status, the respondents were asked to indicate their rank. Of those librarians who provided this information, four were full librarians, eighteen were associate librarians, fourteen were assistant librarians, and four were general librarians. Because there were so few full and general librarians, it was not feasible to report results by rank.

\section{Interaction and Collaboration}

The first part of the survey was designed to determine the level of interaction and collaboration between faculty and librarians. For each area of investigation, the survey asked librarians to report the type of interaction they had with faculty. If there had been no interaction, they were asked to state the reasons. (See table 1.)

\section{Teaching/Instruction}

Of the forty-one respondents, thirty-five (85\%) answered affirmatively to the preliminary question, Have you ever taught a component of a course(s) or provided library instruction for a course(s)? When asked what type of interaction had occurred, not unexpectedly the highest response rates were for training on BISON or NETDOC (77\%) (BISON is the University of Manitoba's online public catalogue; NETDOC is an in-house aggregation of networked databases), followed by providing instruction on database searching (71\%). However, in addition to teaching sessions on the Internet, research methods, and the design and evaluation of library assignments, it was interesting to see that 31 percent of the librarians had been asked to perform "other," more advanced types of teaching, including designing and teaching courses, accessing and transferring statistical data files, and information network development. This would indicate that 


\begin{tabular}{|c|c|c|c|c|c|}
\hline \multicolumn{6}{|c|}{$\begin{array}{c}\text { TABLE } 1 \\
\text { Type of Interaction }\end{array}$} \\
\hline & \# & $\%$ & & \# & $\%$ \\
\hline Teaching/Instruction & & & Creating Web pages & 8 & 27 \\
\hline BISON/NETDOC training & 27 & 77 & $\begin{array}{l}\text { Helping faculty order materials } \\
\text { online }\end{array}$ & 8 & 27 \\
\hline Database searching & 25 & 71 & Developing instructional Web sites & 5 & 17 \\
\hline Internet training & 21 & 60 & Developing or managing databases & 3 & 10 \\
\hline Research methods & 20 & 57 & Other & 5 & 17 \\
\hline $\begin{array}{l}\text { Design/evaluation of library } \\
\text { assignments }\end{array}$ & 17 & 49 & Research & & \\
\hline Other & 11 & 31 & $\begin{array}{l}\text { Working as partner on research } \\
\text { project }\end{array}$ & 10 & 71 \\
\hline Information Services & & & Performing literature searches & 10 & 71 \\
\hline Explaining library services & 36 & 90 & Gathering data & 9 & 64 \\
\hline Finding a fact & 36 & 90 & Analyzing data & 7 & 50 \\
\hline Using BISON/NETDOC & 35 & 88 & Publishing results & 7 & 50 \\
\hline Verifying citations & 35 & 88 & Cowriting proposal & 6 & 43 \\
\hline Researching a topic & 33 & 82 & Creating or managing database & 2 & 14 \\
\hline Conducting a literature search & 30 & 75 & Other & 1 & 7 \\
\hline $\begin{array}{l}\text { Searching for pedagogical } \\
\text { materials }\end{array}$ & 14 & 35 & Collections & & \\
\hline Other & 11 & 28 & $\begin{array}{l}\text { Received recommendations for } \\
\text { purchase }\end{array}$ & 34 & 100 \\
\hline Information Technology & & & $\begin{array}{l}\text { Faculty member is/was departmen- } \\
\text { tal library liaison }\end{array}$ & 29 & 85 \\
\hline $\begin{array}{l}\text { Providing instruction in the } \\
\text { use of software }\end{array}$ & 25 & 83 & $\begin{array}{l}\text { Consulted with faculty for journal } \\
\text { cancellations }\end{array}$ & 29 & 85 \\
\hline $\begin{array}{l}\text { Providing assistance retriev- } \\
\text { ing electronic documents }\end{array}$ & 20 & 67 & $\begin{array}{l}\text { Received request for collection } \\
\text { assessment }\end{array}$ & 26 & 76 \\
\hline Resolving technical problems & 19 & 63 & Developed reading list for course & 14 & 41 \\
\hline $\begin{array}{l}\text { Assessing and recommending } \\
\text { software }\end{array}$ & 12 & 40 & Other & 8 & 24 \\
\hline
\end{tabular}

opportunities are available to librarians to teach sessions that go beyond the basic traditional catalog and database searching.

Of the 15 percent $(n=6)$ of librarians who responded negatively, 83 percent answered it was not part of their responsibilities, 50 percent said they had not been asked to teach, and 33 percent said they had no time available to teach.

\section{Information Services}

The next area of investigation was information services. Respondents were asked: Have you ever provided reference assistance to faculty? As expected, responses to this preliminary question yielded a high positive response rate of 98 percent $(n=40)$. Ninety percent of those who responded affirmatively reported they 
were asked to explain library services or find a fact, not a very advanced level of reference service. The next most highly requested service was to help faculty verify citations and use BISON and NETDOC, followed by researching a topic and then conducting a literature search. The least requested information service was searching for pedagogical materials, mirroring the results of the faculty survey where this was also the least requested type of information service. "Other" information services that were provided included citation searching and analysis, accessing e-journals and Internet resources, and evaluating materials for research.

Since this survey was administered, access to electronic resources has come to the forefront of information service. For example, at the University of Manitoba, the Canadian National Site Licensing Project (CNSLP) and other aggregations have increased the number of electronic journals to nearly eight thousand. ${ }^{12}$ Recent anecdotal reports from librarians indicate that help with accessing electronic resources is one of the most highly requested information services. Because of the complexities in accessing electronic resources, librarians have responded by designing workshops specifically in this area.

\section{Information Technology}

The preliminary question in this area asked: Have you ever provided assistance to faculty in dealing with information technology? Seventy-three percent $(n=30)$ of the librarians said they had provided assistance with information technology and only 27 percent $(n=11)$ said they had not. Among those who had provided assistance with information technology, by far the most frequent type of assistance was "providing instruction in the use of software" (83\%). Although "creating Web pages," "developing instructional
Web sites," and "developing or managing databases" were cited considerably less frequently, anecdotal data suggest that librarians are now more involved in this type of activity. In the "other" comments, more specialized work with data files was cited, as well as instructional technology resource planning and helping to install software.

Of the librarians who responded negatively, less than half said it was not part of their responsibilities. Only 36 percent reported that they did not have sufficient ability or expertise, and the same number indicated they did not have time to provide the assistance.

\section{Research}

At the University of Manitoba, librarians have faculty status, and as such, research is a right and a responsibility. Accordingly, the investigators were most eager to find out the level and type of research collaboration taking place between faculty and librarians. Thus, the preliminary question in the area of research was: Have you ever collaborated with a faculty member on a research project? Slightly more than one-third of the respondents said they had. Of the fourteen librarians who said they had collaborated, 71 percent said they "worked as a partner on a research project" and the same number had "performed a literature search." Although literature searching can be considered a traditional role in the medical field, librarians are now performing systematic reviews of the literature that are crucial to the publication of research papers reviewing clinical trials. As a result, they have been included as authors in the publications. The next highest collaboration was "gathering data," at 64 percent. Fifty percent had "analyzed data" and "published the results," and 43 percent had "co-written the proposal." Only 14 percent stated they had collaborated in 
the "creation or management of a database." One librarian had created a Web teaching and research resource.

Of the 66 percent $(n=27)$ of the librarians who did not collaborate with faculty on a research project, 37 percent stated that they had no time to develop collaborative research with a faculty member. Twenty-six percent stated that it was not part of the institutional culture, and 30 percent said they did not have sufficient subject background or expertise to participate in a faculty member's project. No one thought it inappropriate for a faculty member to be part of a librarian's research project. In the "other" comments, several mentioned they were involved with research that did not lend itself to collaboration with faculty. Others stated that the opportunity for research collaboration with faculty had not arisen or they had not been asked. Only a few thought that this type of activity was not relevant or part of their responsibilities.

\section{Collections}

The preliminary question in the area of collections asked: Have you had any interaction with a faculty member in developing collections? Eighty-three percent $(n=34)$ of the librarians answered that they had. When asked what type of "collections" interaction they had had, all the librarians answered that they had received recommendations for purchase. The next highest levels of interaction with the faculty were a result of journal cancellations and of faculty members being the departmental liaisons (85\%). Seventy-six percent of the librarians had received requests for a collection assessment for a course or program, and 41 percent had been consulted by faculty to develop a reading list for a course. "Other" types of interaction included collaboration on grant applications and the development of collection policies, discussions on Conspectus findings, participation in curriculum committees, and donations to the library. ${ }^{13}$

Of the 17 percent $(n=7)$ who had not had contact with faculty in developing library collections, 86 percent were not involved in collections management and 57 percent had not conducted a collection assessment for a course or program.

In summation, the librarians reported that the highest point of interaction was for information services (98\%), similar to the faculty survey $(88 \%)$. Unlike the faculty responses, where teaching/instruction was ranked fourth $(20 \%)$ and collections second (38\%), librarians reported teaching/instruction as the second most requested function at 85 percent and collections a close third at 83 percent. Providing help with information technology was ranked fourth by 73 percent of the librarians and third by 33 percent of the faculty. Research was rated fifth by both librarians (34\%) and faculty (7\%). (See figure 1.)

\section{Faculty's Impact}

In the faculty survey, the researchers explored the impact of librarians in all five areas of investigation; in this survey, the only areas where it was relevant to measure impact were research and collections. The researchers wanted to know how librarians viewed the faculty's impact on their research and collection activities.

\section{Research}

Of the 34 percent $(n=14)$ of librarians who collaborated with a faculty member on a research project, 50 percent claimed the faculty member's involvement had a very substantial impact, 21 percent maintained that it had a substantial impact, 21 percent said there was some impact, and 7 percent could not rate the impact. None claimed that there was no impact. No one type of impact stood out. Sixty- 
nine percent of the respondents said the faculty member "provided additional expertise and skills," 62 percent felt that he or she "brought a different perspective," another 62 percent said that he or she "provided support for the project," and 46 percent maintained that the collaboration facilitated completion of the research project. The "other" comments were very interesting. One stated that the faculty member's involvement gave some "political" legitimacy to the project; another said that it increased clout in raising funds for the project. In yet another case, the librarian led the project.

\section{Collections}

Twenty-one percent $(n=7)$ of the thirtyfour librarians thought that interaction with faculty members had a very substantial impact on the collections, 41 percent $(\mathrm{n}=14)$ claimed that it had a substantial impact, and 35 percent $(n=12)$ stated that there was some impact. Ninety-four percent of the librarians reported that interaction in the area of collections had improved communication with faculty. This was followed by librarians becoming aware of new resources in their fields (76\%) and in developing better collections $(70 \%)$. Hand in hand with that was the fact that through interaction with faculty, 52 percent of the librarians learned that faculty considered the collections inadequate for a proposed course or program. Another impact reported by librarians was that they had a better understanding of the research needs and teaching interests of faculty.

In conclusion, librarians reported that faculty had a greater degree of impact on their research activities than on collections. The lower impact on collections is probably due to the fact that librarians consider themselves experts in the area of collection-building and see faculty as playing a secondary role. When asked for input in collection development, faculty tend not to respond or to limit their input to their specific area of expertise. On the other hand, librarians have a broader perspective.

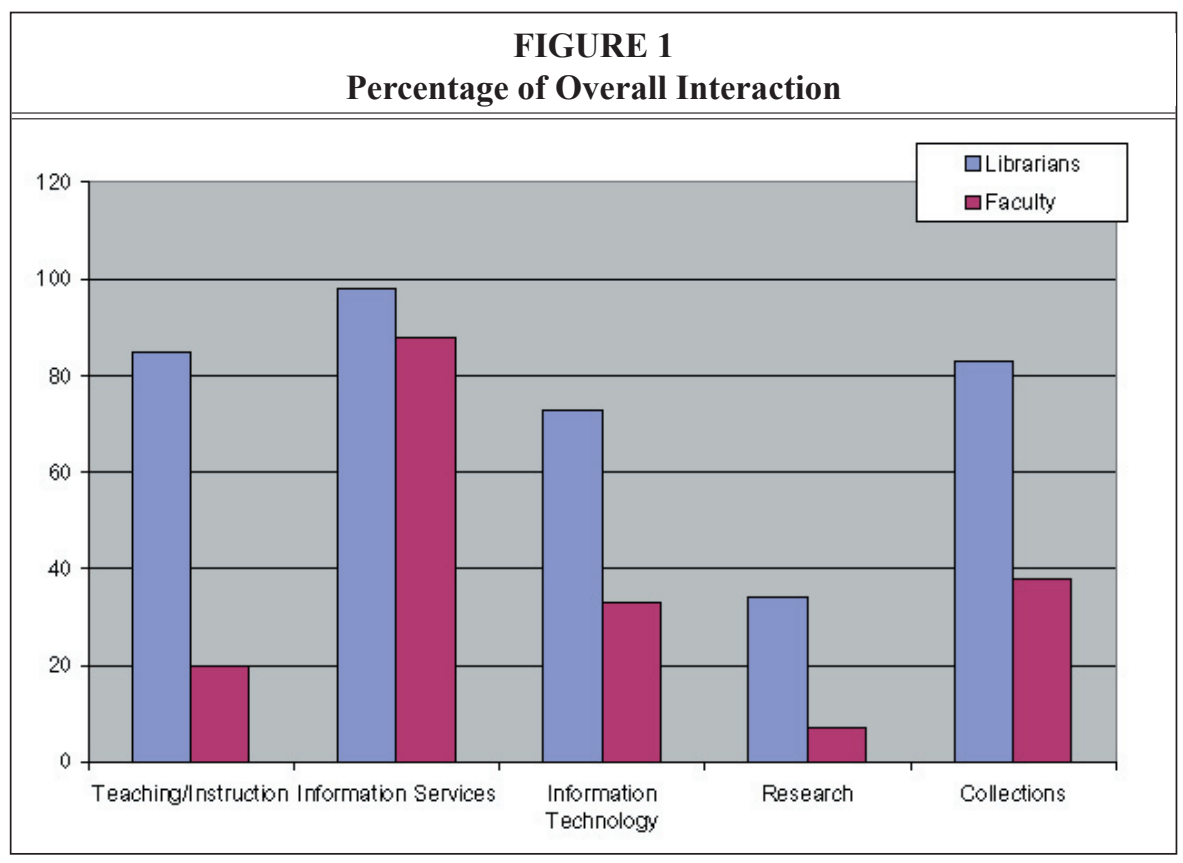




\begin{tabular}{|c|c|c|c|c|c|}
\hline \multicolumn{6}{|c|}{$\begin{array}{c}\text { TABLE } 2 \\
\text { Librarians' Role as Rated by Librarians and Faculty }\end{array}$} \\
\hline & \multicolumn{2}{|c|}{$\begin{array}{l}\text { Very Important/ } \\
\text { Important }\end{array}$} & \multicolumn{2}{|c|}{$\begin{array}{c}\text { Somewhat Important/ } \\
\text { Not Important/ } \\
\text { Can't Rate }\end{array}$} & \multirow{2}{*}{$\begin{array}{c}\begin{array}{c}\text { Pearson } \\
\text { Chi-square }\end{array} \\
\text { p-value* }\end{array}$} \\
\hline & Total \# & Total $\%$ & Total \# & Total $\%$ & \\
\hline Teaching/Instruction & & & & & 0.082 \\
\hline Librarians & 27 & 66 & 14 & 33 & \\
\hline Faculty & 370 & 50 & 361 & 49 & \\
\hline Information Services & & & & & 0.255 \\
\hline Librarians & 38 & 93 & 3 & 5 & \\
\hline Faculty & 620 & 84 & 110 & 15 & \\
\hline Information Technology & & & & & 0.895 \\
\hline Librarians & 28 & 68 & 13 & 31 & \\
\hline Faculty & 509 & 69 & 222 & 30 & \\
\hline Research & & & & & 0.358 \\
\hline Librarians & 28 & 68 & 13 & 32 & \\
\hline Faculty & 437 & 60 & 294 & 40 & \\
\hline Collections & & & & & 0.012 \\
\hline Librarians & 40 & $98^{*}$ & 1 & 2 & \\
\hline Faculty & 590 & 80 & 141 & 20 & \\
\hline
\end{tabular}

\section{Librarian's Role}

The librarians were asked a more general set of questions designed to rate their role in the university community. All were invited to respond regardless of whether they had previously interacted with faculty. The researchers combined the responses to the "very important" and "important" options into one category and merged the responses to the "somewhat important," "not important," and "can't rate" into another category, and compared them to the faculty responses. (See table 2.)

The librarians rated their role as follows in descending order of importance: collections, information services, information technology and research, and teaching/ instruction. As reported in the faculty survey, the faculty ranking is almost identical with information services first, followed by collections, information technology, research, and teaching/instruction.

Not unexpectedly, information services and collections, the areas most traditionally associated with librarianship, were ranked highest by both librarians and faculty. Librarians rated collections as being their most valued function. During the past ten years, the impetus at the University of Manitoba has been to demonstrate the strengths and weaknesses of the collections to the university administration as a means of increasing baseline funding to the libraries. Subject librarians have been increasingly required to perform collection assessments for new courses and programs, the Conspectus, graduate program reviews, and the establishment of research chairs. Because this function has a direct correlation with the funding the 
libraries are able to obtain for collections (and thereby serve clients better), it is not surprising that librarians rate it the highest. Lobbying by libraries administration, supported by the data in the collection assessments, has reaped tremendous benefits.

Teaching/instruction received the lowest rating by both librarians and faculty. It was surprising that librarians ranked teaching the lowest when it was their second highest interaction with faculty at 85 percent. There may be many reasons for this result. For example, it may be that librarians do not feel comfortable teaching because they have not been trained as teachers and, because most library teaching activity is sporadic, they do not have the same level of confidence in their teaching abilities as faculty. Perhaps librarians see teaching as a continuum with their contributions being a very small part of it. David Saia also has contended that librarians have reservations about library instruction because they are overworked or untrained as educators. Some believe bibliographic instruction to be ineffective, some want to have minimal contact with the public, some do not want to teach, and some are threatened by bibliographic instruction. ${ }^{14}$ For a library instruction program to succeed, it must be part of the library's mission and supported strongly by administration. The fact remains that librarians cannot expect faculty to rate their teaching/instruction contributions highly if they themselves do not place a high value on what they do or could do.

Significance tests were performed on the data to compare librarians' responses with the faculty's responses. The results should be viewed with caution because both sets of respondents were nonrandomly sampled (censuses were attempted). In particular, one should interpret $\mathrm{p}$-values as indicators of strength of evidence against the null hypothesis of equality of proportion responding positively in the two groups rather than making a determination of a "significant" difference. Pearson's chi-square test was used to indicate whether librarians and faculty differed with respect to questions regarding the role of librarians at the University of Manitoba. A strong indication of a difference occurred in collections (98\% for librarians and $80 \%$ for faculty, $\mathrm{p}$ $<0.05$ ); a more modest indication of a difference occurred with respect to teaching (66\% for librarians and $50 \%$ for faculty, $\mathrm{p}$ $<0.1$ ). No apparent differences of opinion arose with respect to the other roles.

\section{Expanded Roles}

One of the main purposes of this study was to identify possible future roles for librarians that will enhance the faculty-librarian partnership. For each area of investigation, librarians were asked how else they could contribute. These results then were compared to the responses that faculty provided in these areas. (See table 3.)

With regard to teaching/instruction, respondents were asked: How else could librarians contribute to the teaching process? Their answers were relatively consistent, varying between 51 and 63 percent. The librarians' willingness to collaborate is in sharp contrast with the faculty's lukewarm responses. There are clear differences in proportions responding positively between faculty and librarians for all questions regarding the teaching role ( $\mathrm{p}<0.05$ in all cases). Although 58 percent of the librarians wished to provide assistance with course design and teaching a full course on information literacy, only 11 percent of the faculty stated that they wanted assistance with course design and 17 percent thought that librarians should teach a full course on information literacy. There was less divergence among the responses to helping faculty integrate technology into the curriculum: 63 percent of the librarians thought they could 


\begin{tabular}{|c|c|c|c|c|c|c|}
\hline \multicolumn{7}{|c|}{$\begin{array}{c}\text { TABLE 3 } \\
\text { Librarians' Expanded Roles }\end{array}$} \\
\hline \multirow[b]{2}{*}{ Teaching/Instruction } & \multicolumn{2}{|c|}{ Librarians } & \multicolumn{2}{|c|}{ Faculty } & \multirow[t]{2}{*}{$\begin{array}{l}\text { Chi- } \\
\text { square }\end{array}$} & \multirow[t]{2}{*}{ p-value } \\
\hline & \# & $\%$ & \# & $\%$ & & \\
\hline Providing assistance with course design & 24 & 58 & 83 & 11 & 68.87 & $<0.0001$ \\
\hline $\begin{array}{l}\text { Helping to integrate technology into cur- } \\
\text { riculum }\end{array}$ & 26 & 63 & 322 & 44 & 5.23 & 0.022 \\
\hline Assisting with interactive instruction & 21 & 51 & 221 & 30 & 7.105 & 0.008 \\
\hline $\begin{array}{l}\text { Teaching a full course on information } \\
\text { literacy }\end{array}$ & 24 & 58 & 128 & 17 & 39.03 & $<0.0001$ \\
\hline Other & 9 & 22 & 66 & 9 & 6.05 & 0.014 \\
\hline $\begin{array}{l}\text { Would not consider any other type of } \\
\text { contribution }\end{array}$ & 0 & 0 & 82 & 11 & Fisher* & 0.016 \\
\hline Information Services & \# & $\%$ & \# & $\%$ & & \\
\hline Current awareness service & 27 & 66 & 176 & 24 & 33.09 & $<0.0001$ \\
\hline Citation searching & 20 & 49 & 253 & 34 & 2.89 & $\begin{array}{l}0.089 \\
(\mathrm{NS})\end{array}$ \\
\hline Complete package of information & 16 & 39 & 343 & 47 & 0.64 & $\begin{array}{l}0.422 \\
(\mathrm{NS})\end{array}$ \\
\hline $\begin{array}{l}\text { Identification of key Internet sites in their } \\
\text { field }\end{array}$ & 28 & 68 & 372 & 51 & 4.14 & 0.041 \\
\hline Other & 6 & 15 & 52 & 7 & 2.2 & $\begin{array}{l}0.138 \\
(\mathrm{NS})\end{array}$ \\
\hline $\begin{array}{l}\text { No other information services would be } \\
\text { helpful }\end{array}$ & 0 & 0 & 69 & 9 & Fisher & 0.042 \\
\hline Information Technology & $\#$ & $\%$ & $\#$ & $\%$ & & \\
\hline Assess and recommend software & 7 & 17 & 236 & 32 & 3.43 & $\begin{array}{l}0.063 \\
(\mathrm{NS})\end{array}$ \\
\hline Teach how to use software & 14 & 34 & 227 & 31 & 0.06 & $\begin{array}{l}0.808 \\
(\mathrm{NS})\end{array}$ \\
\hline Create Web pages & 15 & 37 & 188 & 26 & 1.88 & $\begin{array}{l}0.17 \\
(\mathrm{NS})\end{array}$ \\
\hline Develop instructional Web sites & 15 & 37 & 146 & 20 & 5.6 & 0.018 \\
\hline Develop or manage databases & 8 & 20 & 213 & 29 & 1.29 & $\begin{array}{l}0.257 \\
(\mathrm{NS})\end{array}$ \\
\hline $\begin{array}{l}\text { Provide assistance with retrieving elec- } \\
\text { tronic document }\end{array}$ & 20 & 49 & 314 & 43 & 0.35 & $\begin{array}{l}0.553 \\
(\mathrm{NS})\end{array}$ \\
\hline Help faculty order material online & 16 & 39 & 208 & 28 & 1.67 & $\begin{array}{l}0.196 \\
(\mathrm{NS})\end{array}$ \\
\hline Resolve technical problems & 9 & 22 & 204 & 28 & 0.4 & $\begin{array}{l}0.525 \\
(\mathrm{NS})\end{array}$ \\
\hline
\end{tabular}




\begin{tabular}{|c|c|c|c|c|c|c|}
\hline \multicolumn{7}{|c|}{$\begin{array}{c}\text { TABLE } 3 \\
\text { Librarians' Expanded Roles }\end{array}$} \\
\hline \multirow[b]{2}{*}{ Other } & \multicolumn{2}{|c|}{ Librarians } & \multicolumn{2}{|c|}{ Faculty } & \multirow{2}{*}{\begin{tabular}{|c|}
$\begin{array}{c}\text { Chi- } \\
\text { square }\end{array}$ \\
Fisher
\end{tabular}} & \multirow{2}{*}{\begin{tabular}{|c|} 
p-value \\
0.632 \\
(NS)
\end{tabular}} \\
\hline & 0 & 0 & 24 & 33 & & \\
\hline Research & $\#$ & $\%$ & $\#$ & $\%$ & & \\
\hline Cowriting proposal & 25 & 61 & 124 & 17 & 45.79 & $<0.0001$ \\
\hline Creating or managing database & 15 & 37 & 276 & 38 & 0.0001 & $\begin{array}{l}0.972 \\
(\mathrm{NS})\end{array}$ \\
\hline Working as partner on research project & 29 & 71 & 192 & 26 & 35.69 & $<0.0001$ \\
\hline Performing literature search & 31 & 76 & 487 & 66 & 1.11 & $\begin{array}{l}0.291 \\
(\mathrm{NS})\end{array}$ \\
\hline Gathering data & 30 & 73 & 270 & 37 & 20.16 & $<0.0001$ \\
\hline Analyzing data & 23 & 56 & 168 & 23 & 21.31 & $<0.0001$ \\
\hline Publishing results & 26 & 63 & 167 & 23 & 32.19 & $<0.0001$ \\
\hline Other & 3 & 7 & 37 & 5 & Fisher & $\begin{array}{l}0.467 \\
(\mathrm{NS})\end{array}$ \\
\hline $\begin{array}{l}\text { Would not consider another type of col- } \\
\text { laboration }\end{array}$ & 2 & 5 & 103 & 14 & Fisher & $\begin{array}{l}0.152 \\
(\mathrm{NS})\end{array}$ \\
\hline Collections & $\#$ & $\%$ & $\#$ & $\%$ & & \\
\hline $\begin{array}{l}\text { Be members of faculty/departmental com- } \\
\text { mittees }\end{array}$ & 26 & 63 & 191 & 26 & 25.11 & $<0.0001$ \\
\hline Participate in development of courses & 24 & 58 & 163 & 22 & 26.05 & $<0.0001$ \\
\hline Other & 9 & 22 & 31 & 4 & Fisher & $<0.0001$ \\
\hline $\begin{array}{l}\text { Would not consider other ways to build } \\
\text { collections }\end{array}$ & 1 & 2 & 44 & 6 & Fisher & $\begin{array}{l}0.505 \\
(\mathrm{NS})\end{array}$ \\
\hline
\end{tabular}

do so as compared to 44 percent of the faculty. Similarly, 51 percent of the librarians would like to assist with interactive instruction as opposed to 30 percent of the faculty. This polarity also is reflected in the "other" category. Although the librarians' responses (22\%) included providing assistance in designing assignments, team teaching with faculty, and designing online information literacy tutorials, the faculty's responses $(9 \%)$ indicated that they wanted librarians to develop a selfdirected learning package, show students how to think outside the Web, teach stu- dents how to use the Internet effectively, help students evaluate Internet resources, and assist in developing a reference database. Librarians wish to be part of the team in the educational process; however, faculty seem to want librarians to remain within traditional bounds.

However, librarians should take heart. Because traditional teaching methods in higher education are changing and there is less emphasis on didactic classroom presentations, new opportunities will arise where librarians can contribute more fully to student learning. Information 
technology, self-directed learning, and the need to foster critical thinking will require students to go beyond the confines of the classroom to add to their knowledge base. The librarian at the reference desk will be uniquely positioned to provide a point of learning. "Indeed, reference librarians working with individual students or small groups within the library itself can be seen to be teaching in the modeling and mentoring mode, a style not less important for not being recognised as teaching, but rather classed as 'service.' "15 In examining the new teaching roles for academic librarians, several authors have suggested "that the new paradigm for higher education reflects a need to focus on learning, not teaching; that the new learning-centered focus of higher education prizes the importance of learning by doing; and that in this new environment, librarians have new opportunities to play a forceful, dynamic role in collaboratively designing and developing the contexts for learning strategies."16 In fact, Howard L. Simmons is convinced that "most librarians are, first and foremost, teachers ... the librarian in the new millennium will be pushed even more in this direction by a variety of forces both within and outside of the library profession." ${ }^{17}$

In the area of information services, librarians were asked: What other services would you consider providing to faculty? Faculty were asked: What other information services would help you? Faculty had much lower response rates for all the choices with the exception of requesting complete information packages. Almost half of the faculty $(47 \%)$, as opposed to 39 percent of librarians, expressed interest in this type of service. Significant differences were observed for current awareness service and identifying key Internet sites in their field. "Other" responses by librarians included consultation services, collaborative Web development and de- sign, and seminars specifically designed for faculty. Faculty, on the other hand, requested any service that could expedite locating and retrieving literature not held by local libraries, the use of databases, and information on new resources as they become available.

Jordan M. Scepanski suggested that librarians could further expand their role by interpreting and evaluating the information they find: "The librarian of the future will be a refiner of information, not a passive provider of it - and, thereby, will become an active and accepted partner in the educational process." ${ }^{18}$ One example of a new information service is media monitoring. Librarians in some institutions, such as the Library and Archives of Canada, are setting up, controlling, and pushing forward electronic information packages to their clients. ${ }^{19}$ James Wilkinson has seen a role for librarians in filtering the massive amounts of information that faculty must contend with: "Librarians can help direct students and faculty to the most promising sources; they can also help them hone their digital skills on the Internet." 20

In the area of information technology, both librarians (49\%) and faculty (43\%) ranked assistance with retrieving an electronic document the highest. In this category, the only evident difference occurred for the question regarding the development of instructional Web sites, where 37 percent of librarians wanted to develop instructional Web sites as opposed to 20 percent of the faculty who saw a role for librarians in this area. This response is not surprising given that only 20 percent of faculty had ever requested that a librarian teach a component of their courses or provide library instruction. Faculty simply do not see a role for librarians as teachers.

With regard to research, respondents were asked: In what other capacity would you consider collaboration with a faculty 
member/librarian on a research project? Librarians and faculty were close in ranking creating and managing a database, with librarians at 37 percent and faculty at 38 percent. Performing a literature search (librarians $76 \%$, faculty $66 \%$ ) was another area where both groups saw potential for collaboration. In all other areas, faculty were much less receptive to collaboration with librarians. There were strong observed differences with respect to cowriting proposal, gathering data, analyzing data, working with a partner on a research project, and publishing results $(p<0.05$ in all cases). However, librarians can be encouraged by the fact that one quarter of the faculty (26\%) stated that they would be willing to work as partners on a research project with librarians. In turn, librarians possess a strong willingness to work as a partner on a research project with faculty (71\%).

With regard to collections, respondents were asked: How else could faculty help librarians build library collections? This questions provoked very strong differences in proportion of positive response to all questions except for "would not consider any other ways to build collections" ( $p<0.001$ in all relevant cases). Seventy-six percent of the librarians indicated that they would like faculty to investigate obtaining alternate funding for collections. Whereas librarians wanted more inclusion $63 \%$ thought that librarians should be included in faculty/ departmental curriculum committees and $58 \%$ wanted to participate in the development of courses), faculty members were lukewarm to these proposals. Only 26 percent thought librarians should be included in faculty/departmental curriculum committees, and only 22 percent wanted librarians to participate in the development of courses.

Given the new responsibilities that librarians believed they could assume, the authors then wanted them to identify those responsibilities they could relinquish in order to perform any of the new functions. Equipment maintenance (56\%), circulation work $(49 \%)$, and bibliographic checking (39\%) were the most frequently cited functions librarians wished to relinquish. This is not surprising because these functions are not professional in nature and are usually performed by support staff. As well, there are several small libraries in the University of Manitoba system where the reality of the workplace dictates that librarians must frequently step in to perform these duties. Orientation tours, which also do not require professional expertise, were ranked next at 24 percent. The results point to a relatively high degree of dissatisfaction with clerical functions.

Professional responsibilities garnered lower response rates. It was interesting to note that one-fifth of the respondents wished to relinquish committee work. Because committee work is often voluntary, why would these librarians opt not to serve on committees? Furthermore, 17 percent of librarians wanted to relinquish administrative duties. One would assume that these are not librarians whose primary duty is administrative. They may be librarians who perform some administrative functions that do not constitute a large part of their position, but for which they are responsible nonetheless and for which they are not compensated. Twentyseven percent of the librarians did not wish to do Conspectus work. Although Conspectus work is definitely professional in nature, librarians may consider it time-consuming and an added function to an already heavy workload.

It should be noted that future roles for librarians need not be limited to library activities. In fact, some studies show that librarians are more likely to be accepted as academic colleagues if they expand their roles beyond the library. In Jean A. Major's 
study, mature librarians at fourteen ARL libraries reported that they gained acceptance as academic colleagues with the faculty by being well integrated into the governance structure of the universities and by serving on campuswide committees. They noted attitude as another important factor in being accepted as an academic colleague, with self-confidence being a primary attribute and as important as commonly held interests in students, the learning environment, and the value of research. ${ }^{21}$ Irene B. Hoadley also encouraged librarians to become involved in university committees and activities, arguing that their participation would gain them recognition and enable them to influence decisions and provide input. "It is an opportunity to become known rather than remaining part of the sea of faceless ones... . It is a means of legitimizing their roles." 22 This area was not explored by the authors of this article.

\section{Conclusion}

The authors have completed a study of the faculty-librarian partnership based on two surveys - one directed at faculty and the other directed at librarians at the University of Manitoba. Levels and types of interaction between librarians and faculty were examined. Both groups ranked information services as the highest point of interaction and research as the lowest. Although in all areas of investigation, traditional functions ranked high, responses indicated that some librarians are forging ahead in new directions, thus demonstrating that there are opportunities for more effective collaboration with faculty. In the two areas where the faculty's impact on librarians was measured, that is, research and collections, librarians reported that faculty had a higher degree of impact on their research activities than on collections.

When rating the importance of the librarians' role in the university, the order of faculty and librarians' rankings is almost identical. Although librarians had reported a very high level of interaction with faculty in regard to teaching, it was perplexing to find that librarians ranked their teaching role the lowest, as had the faculty.

In examining the possible future roles of librarians, several interesting observations were made. In the area of teaching/ instruction, there was a sharp contrast between the librarians' willingness to collaborate and the faculty's lack of interest. Faculty want librarians to retain their traditional role despite the paradigm shift in higher education. Librarians can work this shift to their advantage because they have competencies and expertise that lend themselves to working with small groups and teaching students to be self-directed. In the area of information services, librarians appear to be willing to expand their role into delivering new services, but faculty seemed less interested in all services proposed with the exception of requesting complete packages of information. More than two-thirds of the librarians indicated a strong willingness to work with faculty on research projects, and a similar number wanted to participate in departmental curriculum committees.

This willingness to venture outside the library walls is a very positive sign. The authors' previous article confirms that faculty are willing to collaborate with librarians at a higher level of interaction than currently experienced..$^{23}$ Success and survival will depend on librarians being proactive-reaching out and participating actively in the academic community.

\section{Notes}

1. Ada M. Ducas and Nicole Michaud-Oystryk, "Toward a New Enterprise: Capitalizing on the Faculty/Librarian Partnership," College E Research Libraries 64 (Jan. 2003): 55-74. 
2. Sheila D. Creth, "A Changing Profession: Central Roles for Academic Librarians," Advances in Librarianship 19 (1995): 85-98.

3. Carla Stoffle, Barbara Allen, and Janet Fore, "Reinventing Academic Libraries and Librarianship," College E Research Libraries News 61 (Nov. 2000): 895.

4. Doug Cook, "Creating Connections: A Review of the Literature," in The Collaborative Imperative: Librarians and Faculty Working Together in the Information Universe, ed. Dick Raspa and Dane Ward. (Chicago: Association of Research Libraries, 2000), 19.

5. Mary Lynn Rice-Lively and J. Drew Racine, "The Role of Academic Librarians in the Era of Information Technology," Journal of Academic Librarianship 23 (Jan. 1997): 31-41.

6. Evan St. Lifer, "Net Work: New Roles, Same Mission," Library Journal 121 (Nov. 15, 1996): 26-30.

7. Bee Gallegos and Thomas Wright, "Collaborations in the Field: Examples from a Survey," in The Collaborative Imperative: Librarians and Faculty Working Together in the Information Universe, ed. Dick Raspa and Dane Ward (Chicago: Association of Research Libraries, 2000), 97-113.

8. Mick O'Leary, "New Roles Come of Age," Online (Weston, Conn.) 24 (Mar./Apr. 2000): 20-22, 24-25.

9. Patrick J. Hunt, "Interpreters as Well as Gatherers: The Librarian of Tomorrow ... Today," Special Libraries 86 (summer 1995): 201.

10. Paul Saffo, "It's the Context, Stupid: In a World of Hyperabundant Content, Point of View Is the Most Valuable Resource," WIRED 2 (Mar. 1994): 74-75.

11. For information on the R statistical software, see http://www.r-project.org/.

12. "The Canadian National Site Licensing Project (CNSLP) is a ground-breaking digital library initiative established by the Canadian research library community to increase the capacity for research and innovation in Canada. Through innovative licensing agreements, CNSLP has secured desktop access to electronic versions of scholarly journals and research databases primarily in science, engineering, health, and environmental disciplines for sixty-four participating universities across Canada." For additional information, see http://www.cnslp.ca/index.php.

13. The Conspectus methodology for collection assessment was developed by the Research Libraries Group in the United States and is used to evaluate university library collections. It assigns "levels" (e.g., 3a-Basic Instructional Support, 3b-Intermediate Instructional Support, 3c-Advanced Instructional Support or Master's Level, 4-Research Support or Doctoral Level) to a library collection by measuring holdings.

14. David Saia, "Advocacy for Bibliographic Instruction: A Challenge for the Future," Katherine Sharpe Review no.1 (summer 1995). Available online at http://alexia.lis.uiuc.edu/review/summer1995/saia.html.

15. Maureen Nimon, "Developing Lifelong Learners: Controversy in the Educative Role of the Academic Librarian," Australian Academic E Research Libraries 33 (Mar. 2002): 14-24.

16. Alice Harrison Bahr, "Introduction," in Future Teaching Roles for Academic Librarians, ed. Alice Harrison Bahr (New York: Haworth Pr., 2000), 3.

17. Howard L. Simmons, "Librarian as Teacher: A Personal View," in Future Teaching Roles for Academic Librarians, ed. Alice Harrison Bahr (New York: Haworth Pr., 2000), 43.

18. Jordan M. Scepanski, "Forecasting, Forestalling, Fashioning: The Future of Academic Libraries and Librarians," in Academic Libraries: Their Rationale and Role in American Higher Education (Westport, Conn.: Greenwood Pr., 1995), 171.

19. Ross Gordon, "Media Monitoring-Get Involved: Why You or Your Library Should Take Control of This Function" Presentation at Manitoba Library Associations Conference, Winnipeg, MB, May 8-9, 2003.

20. James Wilkinson, "From Transmission to Research: Librarians at the Heart of the Campus," in Future Teaching Roles for Academic Librarians, ed. Alice Harrison Bahr (New York: Haworth Pr., 2000), 35.

21. Jean A. Major, "Mature Librarian and the University Faculty: Factors Contributing to Librarians' Acceptance as Colleagues," College E Research Libraries 54 (Nov. 1993): 463-69.

22. Irene B. Hoadley, "Among Friends: Involvement in Academic Collegiality," in The Librarian in the University: Essays on Membership in the Academic Community (Metuchen, N.J.: Scarecrow Pr., 1990), 32.

23. Ducas and Michaud-Oystryk, "Toward a New Enterprise: Capitalizing on the Faculty/Librarian Partnership." 